\title{
Cross Sectional Survey on Equine Gastro Intestinal Stroglylosis and Fasciolosis in Goba District of Bale Zone, Oromia Regional State, Ethiopia
}

\author{
Zewdie Wubishet ${ }^{1}$, Hailu Yacob $^{2}$ \\ ${ }^{1}$ Oromia Pastoralist Area Development Commission, Yabello Regional Veterinary Laboratory, Yabello, Ethiopia \\ ${ }^{2}$ College of Veterinary Medicine and Agriculture, Addis Ababa University, Bishoftu, Ethiopia
}

Email address:

wubevet1921@gmail.com (Z.Wubishet),wubenbe2122@gmail.com (Z.Wubishet)

\section{To cite this article:}

Wubishet Zewdie, Yacob Hailu. Cross Sectional Survey on Equine Gastro Intestinal Stroglylosis and Fasciolosis in Goba District of Bale Zone, Oromia Regional State, Ethiopia. Animal and Veterinary Sciences. Vol. 5, No. 5, 2017, pp. 84-88. doi: 10.11648/j.avs.20170505.14

Received: March 17, 2017; Accepted: March 28, 2017; Published: October 30, 2017

\begin{abstract}
Cross sectional study was conducted on Equine gastro intestinal Strongylosis and Fasciolosis in Goba district of Bale zone Oromia reginal state, Ethiopia. Study involving a total of 384 (218 Horses, 107 Donkeys and 59 Mules) samples were conducted. The study revealed that Gastrointestinal Strongylosis and Fasciolosis are the main problem of equines in the district affecting the wellbeing of horses, mules and donkeys with over all prevalence of $83.3 \%$ and $11.98 \%$, respectively. The occurrence of equine Gastrointestinal Strongylosis and Fasciolosis in this study suggests the importance of the problem in the study area and the overall effect on drought power. There were statistically significant differences $(\mathrm{P}<0.05)$ between (male $V S$ female) and species of equines with regard to Equine Strongylosis. However, there was no statistically significant differences $(\mathrm{P}>0.05)$ with regard to Equine Fasciolosis between (male VS female) and species of equines. There were no statistically significant differences among equine species, age groups $(\mathrm{P}>0.05)$ in prevalence of Equine Fasciolosis. The result of this study disclosed that equine Fasciolosis is main problem of parasitic diseases next to Strongylosis in study area. However, since Equine receive less attention in terms of feeding, health and management cares in study area, it affecting the wellbeing of horses, mules and donkeys. Therefore, due emphasis should be given particularly in prevention and control of the parasites in Equine.
\end{abstract}

Keywords: Equines, Fasciolosis, Goba District, Prevalence, Strongylosis, Survey

\section{Introduction}

Ethiopia has the largest livestock inventories in Africa, including more than 38 million cattle, 30 million small ruminants, 1 million camels, 4.5 million equines and 4 million chickens [1]. It is also known that the country possesses about 5.02 million donkeys, 2.75 million horses and 0.63 million mules. There is one equine for every four people in the agricultural sector and for every five persons of the total population [2]. Ethiopia is home to the oldest feral horse population in Africa and the only wild horses left in east Africa. Arsi and Bale provinces of Oromia regional state are known with their densely populated equine population, mainly in high land of the areas [3].
Equines play a key role in the agricultural economy of the country and are used for pack transportation, riding, carting and threshing farm cultivation among others [4]. In the agricultural communities of Ethiopia, the mule own much of its popularity to the fact that it is more resistant than horse to adverse system of management. Mules are used as drought or pack animals occasionally for riding; they are capable of working and maintaining good condition [5]. Spending hundreds of years being used by man but despite this in past little attempt has been made to study any aspect of this animal. Vast sums of money have been spent on horse by its wealthy owner but the donkey owner has represented as poor populations throughout the world, often hardly able to afford 
medical care for the children, let alone veterinary care for donkey $[6,7,8]$.

The mountains nature of Ethiopian landscape has also made travel time consuming and difficult which has resulted the back of pack animals to remain as the only suitable means of transport in the country terrain for centuries $[6,9,10]$. Equines play an important role in socio-economic development by providing drought power. Equines (donkeys, mules and horses) play an important role as working animals in many parts of the world, employed for packing, riding, carting and ploughing. Equine power is vital for both rural and urban transport system which is cheap and provides the best alternatives in places where the road network is insufficiently developed, the terrain is rugged and mountainous and in the cities where narrow streets prevent easy delivery of merchandise[9]. The optimum utilization of equine was hindered by a variety of diseases among which parasitic diseases are the major ones [8, 11]. Among them helminthes of equine includes Nematodes, Trematodes and Cestodes of which the most common ones are large Strongyles of genes Strongylus (Triodontophorus), the small Strongyles (Trichonemes, cyathostomes), Ascarids (P. equorum), intestinal thread worms (Habronema spp), Trichostronglus axei, Tape worm (Anoplocephala spp), lung worm (Dictyocavlus arnfieldi) and Trematode (Gastrodicus aegptiacus [11].

Equines are hosts to a great number of gastrointestinal parasite species, of which nematodes of the family Strongylidae, commonly called Strongyle nematodes or Strongyles, are the most important. These parasites are ubiquitous and live as adults in the large intestine of equids [8]. The large Strongyles recognized as being the most pathogenic to the equine spps. They belong to genus Strongyles and comprising of three species $S$. vulgaris, $S$. edentatus and $S$. equines. Strongylosis is a serious problem in young horses reared on permanent horse pasture, although cases of sever disease may occur in adult animals kept in suburban paddocks and subjected to overcrowding and poor management $[11,12,4]$. Strongylus vulgaris and Strongylus edentatus are among the most common problems in Ethiopia and more rarely Strongylus equines. On the other hand, Fasciola hepatica is also common in many countries as an occasional parasite of equine and man. Horses and donkeys may get heavy infestation where such case usually discovered at routine postmortem examination [11].

In Ethiopia Equines are found in high lands and middle altitudes mainly using for packing and riding $[13,14]$. These altitudes are known by presence of Fasciolosis in livestock as reported by different workers [13, 15]. Even though these parasites were reported as major Equine problem in different parts of the country Ethiopia, there was no report in Bale Zone of Oromia regional state particularly in and around Goba district. Therefore the objective of the study was:

(1) To determine the prevalence of equine Fasciolosis and gastro intestinal Strongylosis;

(2) To recommend relevant control options pertinent to local situations in study area.

\section{Materials and Methods}

\subsection{Study Area}

Bale Zone is located in the south east of Oromia regional state, southern Ethiopia. The area has high potential in wild life resource and conservations. Bale mountains national park the biggest national park in which endemic wild animal species like Nyala, the Red Fox and numerous species of endemic birds are found. The livelihood of people in and surrounding bale zone are based on mixed farming with same nomadic people/pastoralists living in low lands of the zone mainly depending on livestock production [4]. The altitude of the zone varies from $2,400-4,500$ meters above sea level with an annual rain fall of $1,200-1,400 \mathrm{~mm}$ and mean average temperature of $6-9^{\circ} \mathrm{C}$. Goba is located $443 \mathrm{~km}$ to south east of Addis Ababa with altitude ranging between 2400-4375 meters above sea level. The average annual temperature and rain fall ranges between $12-18^{\circ} \mathrm{C}$ and $900-1400$ respectively.

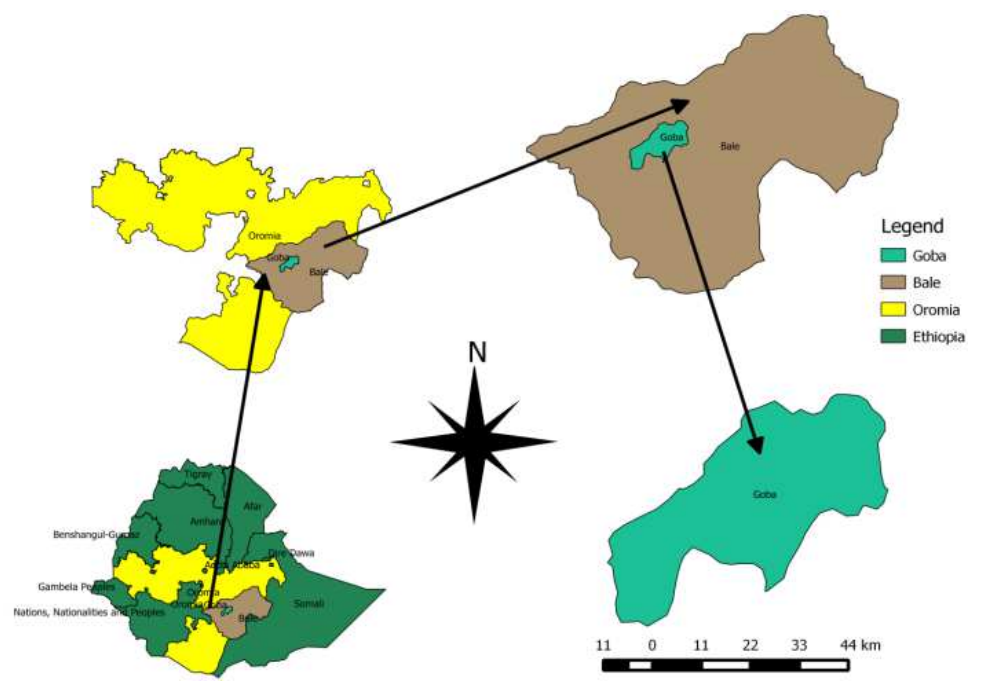

Figure 1. Map of Study area. 
The community in Goba district practice mixed farming (raising livestock and production of crops). They raise cattle, sheep, goats, Equines and poultry. Main crops produced in the districts are wheat, barley, teff, maize, sorghum, pulses, oil crops, horticultural and fruit trees [4]. The animal population in Goba woreda was estimated to be Bovine 88,038; Equine 189,746; Ovine 6334; Caprine 2229 and Poultry 10,851. The management system is extensive and there is high Equine population used for different purposes. Horses, mules and donkeys are mainly used for both riding and as the pack animals (Goba District Agricultural Bureau, 2008).

\subsection{Study Animals}

The Study was conducted on a total of 384 Equine of local breed brought to Goba Veterinary Clinic and Kebeles in the district, Horse 218; Donkeys 107 and 59 Mules including all age and sex groups managed under smallholder mixed croplivestock farming system. All the animals were clinically examined and their age was determined. Equines less than two years of age were considered as young, while those more than two years old as adult as of methodology used by Yoseph [16].

\subsection{Study Design and Type}

Random sampling techniques were applied to Equines brought to goba clinic and Equines in goba district peasant Association (PA) that included in study. The study was conducted using a cross-sectional study design to determine the prevalence of Equine Fasciolosis and gastro intestinal Strongylosis involving the use of simple random sampling technique. The sample size was determined based on expected prevalence of $50 \%$ (as there was no previous report of the prevalence of these parasites in the specific study area); absolute desired precision of 5\% at confidence level of $95 \%$ was used. The sample size was calculated using formula stated by Thrusfield [17].

$$
\mathrm{n}=\frac{1.96^{2} \mathrm{p}_{\mathrm{ex}}\left(1-\mathrm{p}_{\mathrm{xe}}\right)}{d^{2}}
$$

Where $\mathrm{p}_{\mathrm{ex}}$ expected prevalence

$\mathrm{n}$ is required sample

$\mathrm{d}$ desired precision

$1.96 \mathrm{z}$-value for $95 \%$ confidence level

Accordingly, a total of 384 fecal samples were collected for cross sectional survey.

\subsection{Coprological Survey}

For gastro intestinal parasite survey faecal samples were collected from 384 Equines (218 Horses, 107 Donkeys and 59 Mules). The samples were collected directly from the rectum Equines by restraining in humane way of all animals and examined under microscope applying sedimentation flotation and direct examination.

\subsection{Direct Fecal Examination}

In order to determine prevalence of gastro intestinal Strongylosis, a small quantity of faces was taken and placed on slide, mixed with drop of water, spread out covered with a cover slip and examined directly under low power objective of microscope according to the method described by Hendrix [15].

\subsection{Sedimentation Flotation Technique}

Approximately 3 gram of faces was taken and mixed with $42 \mathrm{ml}$ of water. The mixture was poured to test tube and kept for 15-30 minutes. The supernatant was decanted off and the sediment was poured into test tubes. The test tube was filled with saturated salt solution and inverted 5 or 6 times with the thumb over the open and a few drops of saturated salt solution was added until a convex meniscus stand above the top of the tube and allowed to stand for 15 - 30 minutes. Then cover slide was covered over the top of the test tube so that it is in contact with liquid. Finally, the cover glass was placed on slide and examined under low power microscope for the presence of fasciola eggs.

\subsection{Data Analysis}

The prevalence was defined as the proportion of the animals (equines) positive for Fasciolosis and/or gastro intestinal Strongylosis to the total number of animals examined, which was expressed in percent. The difference in the prevalence Equine Fasciolosis and gastro intestinal Strongylosis among or between Equine species, age and sex groups was analyzed by chi-square $\left(X^{2}\right)$ test. $\mathrm{P}<0.05$ was considered as statistically significant.

\subsection{Result}

Out of 384 examined animals, $321(83.6 \%)$ were detected to be positive for gastro intestinal Strongylosis. Out of which, $171(79.4 \%) ; 102(96.3 \%)$ and $48(81.4 \%)$ of horses, donkeys and mules were positive to Equine gastro inestinal Strongylosis. Meanwhile, the overall prevalence of equine Fasciolosis was 46 (11.98\%); Out of which, the prevalence of horses, donkeys and mules were 23 (10.6\%), 15 (14\%) and 8 $(13.6 \%)$, respectively (Table 1 and 2$)$.

Table 1. Prevalence of gastro intestinal Strongylosis in different equine species in and around Goba District.

\begin{tabular}{llll}
\hline Species & Total examined & No. of positive & Prevalence (\%) \\
\hline Donkeys & 107 & 102 & 96.3 \\
Horses & 218 & 171 & 78.4 \\
Mules & 59 & 48 & 81.4 \\
Total & 384 & 321 & 83.6 \\
\hline
\end{tabular}

Table 2. Prevalence of Fasciolosis in different equine species in and around Goba District.

\begin{tabular}{llll}
\hline Species & Total examined & No. of positive & Prevalence $(\%)$ \\
\hline Donkeys & 107 & 15 & 14 \\
Horses & 218 & 23 & 10.6 \\
Mules & 59 & 8 & 13.6 \\
Total & 384 & 46 & 11.98 \\
\hline
\end{tabular}


Table 3. Prevalence of gastro intestinal strongylosis by age in different equine spp in and around Goba District.

\begin{tabular}{lllll}
\hline $\begin{array}{l}\text { Equine } \\
\text { species }\end{array}$ & Age group & $\begin{array}{l}\text { Total } \\
\text { examined }\end{array}$ & $\begin{array}{l}\text { No. of } \\
\text { positive }\end{array}$ & $\begin{array}{l}\text { Prevalence } \\
\text { (\%) }\end{array}$ \\
\hline \multirow{2}{*}{ Horses } & Young & 24 & 21 & 87.5 \\
& Adult & 193 & 150 & 77.7 \\
Donkeys & Young & 23 & 19 & 82.6 \\
& Adult & 84 & 83 & 98.8 \\
Mules & Young & 10 & 8 & 80 \\
Total & Adult & 49 & 40 & 81.6 \\
\hline
\end{tabular}

Table 4. Prevalence of Fasciolosis by age in different equine spp in and around Goba District.

\begin{tabular}{lllll}
\hline $\begin{array}{l}\text { Equine } \\
\text { species }\end{array}$ & Age group & $\begin{array}{l}\text { Total } \\
\text { examined }\end{array}$ & $\begin{array}{l}\text { No. of } \\
\text { positive }\end{array}$ & $\begin{array}{l}\text { Prevalence } \\
\text { (\%) }\end{array}$ \\
\hline \multirow{2}{*}{ Horses } & Young & 24 & 4 & 16.7 \\
& Adult & 193 & 20 & 10.4 \\
Donkeys & Young & 23 & 3 & 13 \\
& Adult & 84 & 12 & 14.3 \\
Mules & Young & 10 & 1 & 10 \\
Total & Adult & 49 & 6 & 12.2 \\
\hline
\end{tabular}

Table 5. Prevalence of gastro intestinal Strongylosis by sex in different equine spp in and around Goba District.

\begin{tabular}{lllll}
\hline $\begin{array}{l}\text { Equine } \\
\text { species }\end{array}$ & Sex group & $\begin{array}{l}\text { Total } \\
\text { examined }\end{array}$ & $\begin{array}{l}\text { No. of } \\
\text { positive }\end{array}$ & $\begin{array}{l}\text { Prevalence } \\
\text { (\%) }\end{array}$ \\
\hline \multirow{2}{*}{ Horses } & Male & 154 & 117 & 75.9 \\
& Female & 64 & 54 & 84.4 \\
Donkeys & Male & 49 & 47 & 95.9 \\
& Female & 58 & 55 & 94.8 \\
Mules & Male & 15 & 8 & 53.3 \\
Total & Female & 44 & 40 & 90.9 \\
\hline
\end{tabular}

Table 6. Prevalence of Fasciolosis by sex in different equine spp in and around Goba District.

\begin{tabular}{lllll}
\hline & Sex group & $\begin{array}{l}\text { Total } \\
\text { examined }\end{array}$ & $\begin{array}{l}\text { No. of } \\
\text { positive }\end{array}$ & Prevalence(\%) \\
\hline \multirow{2}{*}{ Horses } & Male & 154 & 15 & 9.7 \\
& Female & 64 & 9 & 14.1 \\
Donkeys & Male & 49 & 9 & 18.4 \\
& Female & 58 & 6 & 10.3 \\
Mules & Male & 15 & 3 & 20 \\
Total & Female & 44 & 4 & 9 \\
\hline
\end{tabular}

\section{Discussion}

The study indicated that equine Strongylosis and Fasciolosis are major parasitic health problems of all Equine spp in and around Goba with over all prevalence of $83.6 \%$ and $11.98 \%$, respectively. This result is comparable to previous reports on both parasites in different parts of the country. For instance, on equine Fasciolosis in South wollo is $12.2 \%$ [18] and in Menagesha 9\% [16]. The comparative prevalence of equine Strongylosis by sex was $78.6 \%$ in male and $91.6 \%$ in female with significance differences $(\mathrm{p}<0.05)$. This significance difference might be due to the reason that almost all cart horses in and around Goba are males. These horses which use for cart traction are regularly deformed where as females are left to graze on the field and use to transport farm products to market. The attention given to female horses are less, the owners treat their horse whenever they sick. Comparative prevalence of equine Fasciolosis where $11.45 \%$ for male and $8.38 \%$ for female with no significance difference in this value $(p>0.05)$. This insignificance might be due to less attention given to Fasciolosis while treating horses. There were statistically significant difference $(p<0.05)$ in prevalence of Equine Strongylosis between donkeys (96.3\%), horses (79.36\%) and mules $(81.36 \%)$. This difference may be due to absence of regular deworming in donkeys relative to horses and mules. There were no statistically significant differences $(p>0.05)$ in Equine Fasciolosis among donkeys (14.02\%), horses $(11.01 \%)$ and mules $(11.98 \%)$. Admittedly, species of equine were equally susceptible and can be infected. There were no statistically significant difference $(\mathrm{p}>0.05)$ in different age groups of equines for Strongylosis young $(87.8 \%)$ and adult (82.87\%), for Fasciolosis young (14.03\%) and adult (11.6\%). That means all age groups can be equally infected. However, according to Urquhart et al., 1996 the sensitivity to the disease varies and young are highly susceptible to Strongylosis. A total of forty six equine: 23 (10.6\%) horse, $15(14.02 \%)$ donkey and $8(13.6 \%)$ mule were infected by Fasciolosis. This result coincides with [18] who reported $13.1 \%$ donkeys, $12.8 \%$ horses and $6.5 \%$ mules in South wollo zone of Amara regional state. On the other hand [16] who reported $9 \%$ prevalence in donkeys in Menagesha district.

Three hundred seventy one equine: 171 (79.36\%) horses, $102(96.3 \%)$ donkeys and $48(81.36 \%)$ mules were found infected with Strongylosis. This finding is in agreement with different previous reports $[16,19,5]$ in different parts of the country with prevalence varying $50 \%$ to $100 \%$. The maintenance of fasciolosis in equine may be related with grazing field of equine with ruminants which are considered to be the prominent primary hosts of liver fluke and the environmental condition which allow multiplication and spread of intermediate host snails and presence of parasite in study area. And infection of equines by strongylosis related to grazing field and contamination of pasture with egg of the parasite.

\section{Conclusions and Recommendations}

Through equines considerably contribute to the existing rural and urban economy of nation received less attention in terms of feeding, health and management cares. The optimum utilization of equine was hindered by a variety of diseases among which parasitic diseases are the major ones. The occurrence of equine Gastrointestinal Strongylosis and Fasciolosis in the study suggests the importance of the problem in the study area and the overall effect on drought power. The study result showed that Fasciolosis is prevalent next to Strongylosis which is most prevalent parasitic disease of Equines in study area. The study revealed that Gastrointestinal Strongylosis and Fasciolosis are the main 
problem of equines in in study area affecting the well being of horses, mules and donkeys with over all prevalence of $83.3 \%$ and $11.98 \%$, respectively. Therefore, epidemiology, seasonal dynamic of infection and economic importance of disease in study area should be studied to develop and practice integrated, cost effective and strategic treatment and control options pertinent to local situation.

\section{References}

[1] Central statistics Authority of Ethiopia CSA (2004): Addis Ababa, Ethiopia.

[2] EARO (1999): National animal health research program strategy document; Ethiopian Agricultural Research Organization (EARO), Addis Ababa, Ethiopia, PP. 1-49.

[3] Equines (2012): Horse breeds from Ethiopia. Online: www.info[at] the equinest.com.

[4] Admasu, G., Zelalem, A. and Ayele, G. (2014): Prevalence of Strongyle Parasites in Working Horses in Goba Woreda, Bale Zone, Ethiopia. European Journal of Biological Sciences 6 (3): 66-70.

[5] Bereket, M., Yalelet, W., Abebe, Sh. and Alemgezahu, M. (2015): Prevalence of strongyle infection and associated risk factors in equine in Menz Keya Gerbil District, North-Eastern Ethiopia. Academic Journal, Vol. 7(4), pp. 117-121.

[6] Feseha G. A, Yilma, J. M, Svendesen E. D. and Mohammed A (1991): Health problem of working donkeys in Debre Zeit and Menagesha region of Ethiopia.

[7] Komwenda W. and Mateyo L. (1990): Donkey, Mules and Horses in Tropical agricultural Development, the potential and utilization of Donkeys in Malawi. Pp. 30.

[8] Bariisoo, M. and Wubit, T.(2016): Prevalence of Strongyle Infection and Associated Risk Factors in Horse and Donkeys in and Around Batu Town, Eastshoa, Oromia Regional State, Ethiopia. Food Science and Quality Management www.iiste.org ISSN 2224-6088 (Paper) ISSN 2225-0557 (Online) Vol. 54.

[9] Getachew, M. G., Feseha, A., Trawford, S. W and Reid, J.
(2008): A survey of seasonal patterns in strongyle faecal worm egg counts of working equids of the central midlands and lowlands, Ethiopia. Tropical Animal Health and Production, 40: 637-642.

[10] Zewdu, S., Mulualem, T. and Samuel D. (2015): Prevalence, intensity and risk factors of infestation with major gastrointestinal nematodes in equines in and around Shashemane, Southern Ethiopia. Tropical Animal Health and Production, Vol. 47(8), pp 1515-1521.

[11] Urquhart G. M., Arnovrm, J. L., Dincan J. L., Jennings F. W. and Duncan, J. L. (1996): Veterinary Parasitology $2^{\text {nd }}$ ed. Blackwell Science, London 42-47.

[12] Abayensh, T., F. Gebreab, B. Zekariasand G. Tadese (2002): The potential role of equines in land tillage in central Ethiopia. Bulletin Animal Health and production in Africa, 50: 172-178.

[13] Dinka A (1996): Preliminary Study on Prevalence of Fasciolosis in small ruminants (ovine, caprine) in and around Asela (Arsi). DVM Thesis; Faculty of Veterinary Medicine Addis Ababa University, Debre Zeit, Ethiopia.

[14] Robera, Ch., Negesse, M., Yimer, M. and Waktole, T. (2016): Study on Prevalence of Internal Parasites of Horses in and Around Ambo Town, Central Ethiopia. American-Eurasian Journal of Agriculture \& Environmental Science, 16 (6): 1051-1057.

[15] Hendrx C. M (1998): Diagnostic veterinary Parasitology $2^{\text {nd }}$ ed. st. Lovis London. Philadelphia Sydney Toronto PP 48-59.

[16] Yoseph S, Feseha G and Abebe W. (2005): Survey on helminthosis of equine in Wonchi, Ethiopia. Journal of the Ethiopian Veterinary Association, 5, 47-61.

[17] Thrusfield M. (2004) Veterinary Epidemiology $2^{\text {nd }}$ ed. Black well science UK at University Press, Cambridge, PP. 220.

[18] Seid A. (2007): Study on prevalence of equine Fasciolosis in south wollo zone of Amhara Regional State. DVM Thesis; Faculty of Veterinary Medicine Addis Ababa University, Debre Zeit.

[19] Ashenafi, A., Samuel, E., Natnael, M and Shiret, B. (2015): Prevalence of Gastro Intestinal Nematode Parasitic Infections of Horses and Donkeys in and Around Kombolcha town. Journal of Scientific Research 10: 228-234. 